\title{
Purine Derivative Excretion in Dairy Cows: Endogenous Excretion and the Effect of Exogenous Nucleic Acid Supply
}

\author{
M. Gonzalez-Ronquillo,† J. Balcells, ${ }^{*}$ J. A. Guada, ${ }^{*}$ and F. Vicente \\ *Departamento de Producción Animal y Ciencia de los Alimentos, \\ Universidad de Zaragoza, Miguel Servet 177, 50013 Zaragoza, Spain \\ †Departamento de Producción Animal, FMVZ. Universidad Autónoma del Estado de México.50090, Toluca, Mexico
}

\section{ABSTRACT}

An experiment was conducted with dairy cows to study the partitioning of excreted purine derivatives between urine and milk and to quantify the endogenous contribution following the isotopic labeling of microbial purine bases. Three lactating cows in their second lactation that had been cannulated in the rumen and the duodenum were fed a mixed diet (48:52, roughage/concentrate ratio) distributed in equal fractions every $2 \mathrm{~h}$, and duodenal flow of purine bases was determined by the dual-phase marker system. Nitrogen-15 was infused continuously into the rumen to label microbial purine bases, and the endogenous fraction was determined from the isotopic dilution in urinary purine derivatives. Urinary and milk recovery of duodenal purine bases were estimated at early (wk 10) and late (wk 33) lactation by the duodenal infusion of incremental doses (75 and $150 \mathrm{mmol}$ purine bases/d) of RNA from Torula yeast. Each period was 6 d, with RNA being infused during the last $4 \mathrm{~d}$, followed by measurement of the flow of purine bases to the duodenum. The isotope dilution of purine derivatives in urine samples confirmed the presence of an endogenous fraction (512 $\pm 36.43 \mu \mathrm{mol} /$ $\mathrm{W}^{0.75}$ or $56.86 \mathrm{mmol} / \mathrm{d}$ ) amounting to $26 \pm 3.8 \%$ of total renal excretion. Total excretion of purine derivatives in urine plus milk was linearly related to the duodenal input of purine bases, but the slopes differed $(P<0.005)$ between lactation stages resulting in a lower equimolar recovery in early $(\mathrm{y}=58.86( \pm 3.89)+0.56( \pm 0.0164) \mathrm{x} ; \mathrm{r}$ $=0.90)$ than late lactation $(\mathrm{y}=58.86( \pm 3.89)+0.70$ $( \pm 0.046) \mathrm{x} ; \mathrm{r}=0.80)$. Excretion of purine derivatives through milk represented a minimum fraction of total excretion but responded significantly to the duodenal input of purine bases. No differences between lactation stages were detected, and variations in milk yield did modify significantly the amount of purine derivatives excreted through the milk.

Received February 20, 2002.

Accepted October 10, 2002.

Corresponding author: J. Balcells; e-mail: balcells@posta. unizar.es.
(Key words: dairy cow, purine derivative, microbial synthesis, urinary and milk excretion)

Abbreviation key: $\mathbf{C t}=$ creatinine, $\mathbf{C T}=$ creatinine excretion, $\mathbf{P B}=$ purine bases, $\mathbf{P D}=$ purine derivatives.

\section{INTRODUCTION}

The determination of rumen microbial yield is laborious and imprecise. It also requires animals fitted with abomasal or duodenal cannulas, doubtfully representative of their intact counterparts, such as high-yielding dairy cows.

The excretion of urinary purine derivatives (PD; i.e., allantoin and uric acid) may constitute an alternative noninvasive technique based on the principle that the bulk urinary PD is derived from microbial nucleic acid flowing out from rumen. Several authors (Chen et al., 1990b; Balcells et al., 1991; Giesecke et al., 1994; Orellana-Boero et al., 2001) have confirmed the relationship between the duodenal supply of RNA and the urinary excretion of $\mathrm{PD}$, although such a relationship is usually obscured by an endogenous fraction coming from the turnover of nucleic acid in tissues and the incomplete urinary recovery of infused purines. The magnitude of the endogenous fraction is not constant among species (Chen et al., 1990a; Orellana-Boero et al., 2001) or within species (European-Bos taurus vs. Zebu cattleBos indicus; Liang et al., 1994), and it is not known whether it may be affected by differences in the production rate or the physiological status.

Incomplete urinary recovery of absorbed purine bases (PB) has been reported (Chen et al., 1990b; Balcells et al., 1991); saliva (Chen et al., 1991; Surra et al., 1997) and milk (Giesecke et al., 1994; Martín-Orúe et al., 1996) are the proposed nonrenal routes of PD excretion. In dairy cows, the input/output relationship between duodenal and urinary purines may be modified if the excretion rate of PD throughout the mammary gland is altered by unidentified factors. Therefore, kinetics of PD excretion in milk need study to complete or refine the response model in dairy cows. This information may also open the possibility of using milk samples to moni- 
Table 1. Ingredients and chemical composition of the roughage and concentrate fractions of experimental diets.

\begin{tabular}{|c|c|c|c|c|}
\hline Ingredients & Concentrate & & $\begin{array}{l}\text { Roughage } \\
\text { (wk 11-13) }\end{array}$ & $\begin{array}{l}\text { Roughage } \\
\text { (wk 30-33) }\end{array}$ \\
\hline \multicolumn{5}{|l|}{ Ingredients (\%) } \\
\hline Corn grain & 30 & & & \\
\hline Barley grain & 32 & & & \\
\hline Wheat bran & 10 & & & \\
\hline Soybean meal & 24 & & & \\
\hline Vit/mineral supplement & 4 & & & \\
\hline Alfalfa hay & & & 36 & 66 \\
\hline Vetch-oat hay & & & 53 & 23 \\
\hline Sugar beet pulp (SBP) & & & 11 & 11 \\
\hline $\begin{array}{l}\text { Chemical composition } \\
\mathrm{g} / \mathrm{kg} \text { fresh matter }\end{array}$ & Concentrate & Alfalfa hay & Vetch-oat hay & SBP \\
\hline DM (g/kg DM) & 870 & 910 & 860 & 900 \\
\hline $\mathrm{OM}$ & 921 & 873 & 848 & 892 \\
\hline $\mathrm{CP}$ & 168 & 175 & 247 & 108 \\
\hline NDF & 222 & 358 & 443 & 432 \\
\hline $\mathrm{ADF}$ & 60 & 278 & 216 & 231 \\
\hline Lignin & 13 & 25 & 44 & 26 \\
\hline
\end{tabular}

tor rumen microbial synthesis in lactating animals (Giesecke et al., 1994).

The objective of the present experiment was to observe the partitioning of excreted PD between urine and milk in dairy cows, to determine the difference between early and late lactation, and to quantify the endogenous contribution using the labeling technique described by Orellana-Boero et al. (2001).

\section{MATERIALS AND METHODS}

\section{Animals and Diets}

Three multiparous crossbred Holstein-Friesian cows with $560 \pm 10 \mathrm{~kg}$ of average BW and fitted with a simple cannula in rumen $(6.5$-cm internal $\varnothing)$ and a T-shape cannula in the proximal duodenum $(5 \mathrm{~cm}$ distal to the pylorus) were housed in a tie-stall barn and fed a mixed diet (48:52, roughage/concentrate ratio) offered in 12 equal fractions every $2 \mathrm{~h}$. Ingredients and chemical composition of the diets are detailed in Table 1. Refusals were removed and weighed daily. Water was continuously available, and cows were milked twice daily at 0800 and $1700 \mathrm{~h}$.

\section{Experimental Procedures}

Urinary recovery of duodenal $P B$. The recovery of duodenal PB as urinary PD was determined at two lactation stages: early (10 to $13 \mathrm{wk}$ ) and late lactation (30 to $33 \mathrm{wk}$ ), following the similar procedure during a 26-d experimental period. The duodenal flow of PB was determined by the dual marker system (Faichney, 1975), using Cr-EDTA (120 mg/kg of DMI) and Ytter- bium acetate ( $50 \mathrm{mg}$ of $\mathrm{Yb} / \mathrm{kg}$ of DMI) as liquid and solid markers. From d 1 to 12 both markers were infused into the rumen at a constant rate through two independent lines, using a peristaltic pump (Minipuls-2 HP 18 Gilson), and duodenal digesta was periodically sampled $(250 \mathrm{ml})$ at 6 -h intervals from d 10 to 12 . To modify the duodenal flow of $\mathrm{PB}$, two doses (83 and $160 \mathrm{mmol} / \mathrm{d}$ ) of RNA from Torula yeast (Sigma Chemical Co., St. Louis) were continuously infused into the duodenum in two successive $96-\mathrm{h}$ periods, from d 14 to 18 and from d 20 to 24 , allowing $48 \mathrm{~h}$ for changeover. Urine was collected during the last $72 \mathrm{~h}$ of each infusion period. The infused doses were calculated to be equivalent to the increase in microbial purine flow promoted by increments of 1.3 and 1.6 times maintenance in the level of feeding.

The RNA solution was prepared by diluting the yeast in $4 \mathrm{~L}$ of alkalinized $(1 M \mathrm{NaOH})$ water $(\mathrm{pH} 10)$ at $40^{\circ} \mathrm{C}$. Once the yeast was diluted, the $\mathrm{pH}$ was brought with $1 M \mathrm{HCl}$ to the average recorded in the chymus $(\mathrm{pH}$ 3 to 4 ), and the RNA solution was infused into the duodenum at a flow rate of $1.9 \mathrm{ml} / \mathrm{m}$. Samples of duodenal digesta collected during $48 \mathrm{~h}$ each period were refrigerated and pooled on individual basis at the end of the collection period. Samples of whole and solid digesta were obtained according to Faichney (1975) and freezedried for subsequent analyses.

Finally, from d 24 to 26 urine was daily collected on $200 \mathrm{ml}$ of a sulphuric acid solution (10\% vol/vol) by means of external separators stuck on the vulva. Daily samples were pooled on individual animal bases, after recording the weight and the specific gravity, and two subsamples $(1 \%)$ taken and stored at $-20^{\circ} \mathrm{C}$. To account for possible losses during urine collection, inuline (from 
Dahlia tuber 9005-80-5; Sigma Chemical Co.) diluted in saline solution $\left(0.15 \mathrm{M}\right.$; ClNa) $17.4 \mathrm{~g} / \mathrm{L}$ at $60^{\circ} \mathrm{C}$, filtered (0.45 $\mu \mathrm{m}$, Millipore, Bedborf, MA), and sterilized $\left(100^{\circ} \mathrm{C}, 30 \mathrm{~min}\right)$, was infused for $36 \mathrm{~h}$ via temporary jugular catheter at a flow rate of $0.4 \mathrm{ml} / \mathrm{min}$.

Creatinine excretion (CT, $\mathrm{mg} / \mathrm{min}$ ) was estimated from the infusion rate of inuline ( $\mathrm{mg}$ per minute). Creatinine and inuline were assumed to be in equilibrium in the body liquid pools when urinary inuline/creatinine ratio (inuline/Ct) reached a constant or "plateau" value. Then urinary creatinine was subsequently used to calculate the daily excretion of urinary compounds (for details see Martín-Orúe et al., 2000).

Endogenous measurements. The endogenous contribution to the urinary excretion of PD was estimated after 16 wk of lactation from the isotopic enrichment ratio of urinary $\mathrm{PD}$ to duodenal $\mathrm{PB}$ after labeling microbial $\mathrm{PB}$ by continuous infusion of ${ }^{15} \mathrm{~N}$ into the rumen. The isotope was supplied as ammonium sulphate $\left[\left({ }^{15} \mathrm{NH}_{4}\right)_{2} \mathrm{SO}_{4}, 10^{+}\right.$atom $\%{ }^{15} \mathrm{~N}$, ISOTEC, Inc.) to provide $70 \mathrm{mg}{ }^{15} \mathrm{~N}$ per day during $7 \mathrm{~d}$ (d 6 to 12), infused together with the Cr-EDTA infusate. After the isotope infusion $(0 \mathrm{~h})$ began, total urine was collected in five periods: 0 to 24,24 to 48,48 to 72,72 to 84 , and 84 to $96 \mathrm{~h}$. Next, duodenal digesta was sampled every $6 \mathrm{~h}$ for $48 \mathrm{~h}$. It was assumed that 48 to $72 \mathrm{~h}$ are needed to homogeneously distribute the isotope within the rumen ecosystem and that $24 \mathrm{~h}$ elapsed from duodenal absorption of PB to urinary excretion of purine compounds (for details see Orellana-Boero et al., 2001).

Analytical procedures. Dry matter was determined by drying to constant weight at $105^{\circ} \mathrm{C}$ and $\mathrm{OM}$ by ashing at $550^{\circ} \mathrm{C}$ for $8 \mathrm{~h}$. Total $\mathrm{N}$ content was determined by the Kjeldahl method, using Se as a catalyst. Purine derivatives and creatinine in urine were determined by HPLC following Balcells et al. (1992). Purine bases were analyzed in the chyme after perchloric acid hydrolysis following Martín-Orúe et al. (1995). Concentrations of $\mathrm{Cr}$ and $\mathrm{Yb}$ in digesta and infusates were determined by atomic absorption spectrometry using a nitrous oxide-acetylene flame, after solubilization of markers from ashed samples (Siddons et al., 1985). The isotope enrichment of ${ }^{15} \mathrm{~N}$ in $\mathrm{PB}$ and allantoin was determined with a mass spectrometer (VG PRIM II; IRMS connected in series to a DUMAS-style $\mathrm{N}$ analyzer EA 1108.CARLO ERBA). Urinary allantoin-N was isolated after its conversion to allantoic acid by alkali hydrolysis and extraction by ion-exchange chromatography following Perez et al. (1998). PB-N for isotope analysis was extracted by specific precipitation with $\mathrm{Ag}$ ions as Agcomplex following the Aharoni and Tagari (1991). Inuline in urine and infusates was analyzed colorimetrically following Jung et al. (1990).
Calculations and statistical analysis. Nutrient flow to the duodenum was calculated in reference to Cr-EDTA and Yb-Acetate as fluid and particle marker, respectively, following the Faichney (1975) procedure. The proportion of urinary PD coming from endogenous sources was calculated at steady state conditions as follows:

$$
\begin{gathered}
\text { Endogenous contribution }=1-\left[\text { Urinary } \mathrm{PD}{ }^{15} \mathrm{~N}\right. \\
\text { atom } \% \text { excess (ape) / Duodenal } \mathrm{PB}^{15} \mathrm{~N} \\
\text { atom \% excess (ape)]. }
\end{gathered}
$$

The ${ }^{15} \mathrm{~N}$ atom excess of urinary PD or duodenal PB was obtained using the same unlabeled compounds as a reference.

The CT (mg per minute) rate was calculated by inuline infusion (mg per minute) and urinary inuline: creatinine $[\mathrm{i} / \mathrm{Ct}]$ ratio $\left[\mathrm{Ct}=\mathrm{I} / \mathrm{i} / \mathrm{cr}_{\mathrm{A}}\right]$ when inuline reached equilibrium within the liquid body pools. Equilibrium times were determined in a previous trial (Martín-Orúe et al., 2000) where time evolution of (inuline/CT) ratio was described as a mono-exponential function $\mathrm{Y}=\mathrm{A}$ (1$\left.\mathrm{e}^{-\mathrm{kt}}\right)$, with $Y$ being the inuline/CT value, t: times after infusion times and A: the "plateau" or asymptotic value of inuline/CT to be reached at equilibrium time $\left(t_{(A)}\right)$.

The effect of duodenal flow of PB on the urinary excretion of PD was assessed using the general linear models procedure of SAS (SAS, 1988), fitting the effects of cow and level of PB infusion. Lactation periods were compared by linear regression analysis and homogeneity test procedures (Steel and Torrie, 1980). The effect of duodenal flow of PB and milk yield on milk excretion of PD was analyzed by stepwise regression (SAS, 1988).

\section{RESULTS AND DISCUSSION}

The animals remained in good health during the experiment, and no disturbance was detected due to the infusion procedure. Total milk production averaged $8000 \mathrm{~kg}$ (12-mo lactation), and daily milk yield decreased from $26 \pm 0.55$ to $17 \pm 0.82 \mathrm{~kg} / \mathrm{d}$ between early and late lactation periods $(P<0.001)$. Body weight also changed throughout lactation, recording $\mathrm{BW}$ losses in early lactation $(1100 \pm 50.0 \mathrm{~g} / \mathrm{d})$ and $\mathrm{BW}$ gains in the late-lactation period $(800 \pm 86.7 \mathrm{~g} / \mathrm{d})$. However DMI was similar in early and late lactation, 16.38 and $16.28 \mathrm{~kg} /$ $\mathrm{d}$, respectively, although the variation in roughage composition affected both DM digestibility ( 74.2 vs. $64.6 \%$, respectively) and digestible $\mathrm{OM}$ intake (10.8 vs. 9.6 $\mathrm{kg} / \mathrm{d}$ ).

Xanthine and hypoxanthine were found only inconsistently and in trace amounts in urine samples, and therefore the sum of allantoin plus uric acid was assumed to account for all the PD excreted in urine. On 
Table 2. Natural and induced isotopic abundance $\left[{ }^{15} \mathrm{~N} \%{ }^{14} \mathrm{~N}\right.$ atom] in duodenal and urinary purine compounds after ruminal supply of the isotope $\left[\left({ }^{15} \mathrm{NH}\right)_{2} \mathrm{~S}_{4} 10+\right.$ atom $\left.\%{ }^{15} \mathrm{~N}\right]$.

\begin{tabular}{llllll}
\hline Animal & Cow 1 & Cow 2 & Cow 3 & Mean & SD \\
\hline Natural abundance \% [Standard I.A.E.A. 0.3663] & & & & & \\
Purine bases-N & 0.3697 & 0.3723 & 0.3705 & 0.3708 & 0.0007 \\
Allantoin-N & 0.3690 & 0.3670 & 0.3683 & 0.3683 & 0.0006 \\
Induced abundance (\%) & & & & & \\
Duodenal purine bases-N & & & & \\
$\quad$ Whole digesta & 0.4991 & 0.4885 & 0.4772 & 0.4882 & 0.0063 \\
Solid digesta & 0.5069 & 0.4645 & 0.4916 & 0.4876 & 0.0124 \\
$\quad$ Reconstituted digesta & 0.4977 & 0.5145 & 0.4785 & 0.4969 & 0.0104 \\
Allantoin-N [80-96h] & 0.4540 & 0.4731 & 0.4543 & 0.4602 & 0.0060 \\
Endogenous fraction & 0.326 & 0.261 & 0.208 & 0.263 & 0.0375 \\
\hline
\end{tabular}

${ }^{1}$ Endogenous fraction $=1-$ [Urinary $\mathrm{PD}{ }^{15} \mathrm{~N}$ atom $\%$ excess (ape) $/$ Duodenal $\mathrm{PB}^{15} \mathrm{~N}$ atom $\%$ excess (ape)].

average allantoin accounted for $94.5 \pm 1.02$ and 98.03 $\pm 0.08 \%$ and uric acid for $5.5 \pm 1.02$ and $1.7 \pm 0.08$ in early and late lactation.

\section{Urinary Excretion of Creatinine}

Although urine was collected using external separators attached to the vulva, some urine losses were detected, and inuline was used (Martín-Orúe et al., 2000) to estimate urinary excretion of creatinine as an internal marker of renal excretion. The infusion rate of inuline $\left(50 \mu \mathrm{g} / \mathrm{min}\right.$ per $\left.\mathrm{BW}^{0.75}\right)$ was reduced to the minimum detection level to avoid any disturbance to the animals, although it was not possible to analyze adequately inuline in plasma samples. Equilibrium time of inuline in the plasma pool was assumed to be achieved when values reached the maximum (plateau) of the mono-exponential function described previously $(\mathrm{Y}=\mathrm{A}$ (1 $\left.\mathrm{e}^{-\mathrm{kt}}\right)$ ) following the original method (Martín-Orúe et al., 2000). Average values of CT from urine collection (674.5 \pm 161.5 and $644 \pm 58 \mu \mathrm{mol} / \mathrm{kg} \mathrm{BW}^{0.75}$ for phases I and II, respectively) were significantly lower than those values estimated by inuline dilution (1015 \pm 30.9 and $931 \pm$ $78.8 \mu \mathrm{mol} / \mathrm{kg} \mathrm{BW}^{0.75}$ ) and also more inconsistent (coefficient of variation: CV in phase I was 3 and $23 \%$ for urine collection or inuline dilution data). It confirms the existence of urinary losses from the collector observed experimentally. Total collection values were also lower than those values reported in literature in dairy cows (from 930 to $1225 \mu \mathrm{mol} / \mathrm{kg} \mathrm{BW}^{0.75}$ [Susmel et al., 1994; Gonda et al., 1996; Vagnoni and Broderick, 1997]); consequently, in the present work CT estimated from inuline dilution was considered as the true value and used to correct the experimental losses.

\section{Endogenous Excretion of Purine Derivatives}

The natural and induced isotopic abundance of duodenal purine bases and urinary allantoin are presented in Table 2. Difference in natural abundance between digesta and urine compounds is consistent with previous results (Orellana-Boero et al., 2001) and would reflect discrimination between the atom and the isotope $\left({ }^{14} \mathrm{~N}\right.$ vs. $\left.{ }^{15} \mathrm{~N}\right)$ in some metabolic processes (Wattiaux and Reed, 1995). The isotopic enrichment of duodenal PB did not vary significantly between digesta fractions although the higher level of induced ${ }^{15} \mathrm{~N}$ abundance $(0.5026 \pm 0.054)$ found in bacterial PB might explain the slight increase in ${ }^{15} \mathrm{~N}$ abundance recorded in the reconstituted digesta if bacteria are assumed to be mainly carried in the liquid fraction.

The ${ }^{15} \mathrm{~N}$ enrichment of urinary allantoin increased rapidly during the first $24 \mathrm{~h}$ period and leveled off at about $72 \mathrm{~h}$. Enrichment time course was consistent with previous observations suggesting that $48 \mathrm{~h}$ are needed to obtain a homogeneous distribution of the isotope in the rumen (Broderick and Merchen, 1992) and that a 24-h elapse before a urinary response is obtained following duodenal absorption (Chen et al., 1990b; Balcells et al., 1991). Consequently, we assumed that isotopic dilution in urinary allantoin- $\mathrm{N}$ is due to an endogenous fraction coming from the host nucleic acid turnover. Isotopic enrichment of the urinary allantoin showed that $26.3 \%$ of the urinary PD comes from endogenous sources. The low concentrations of uric acid in urine samples do not allow a confident determination of its enrichment, and therefore only allantoin data are presented. Considering that allantoin contributes up to 95\% of total PD excreted in urine, enrichment variations between uric acid and allantoin may have little significance. The variation (CV) when expressed as millimoles per day was $6.3 \%$ without any improvement when data were expressed as kilograms of metabolic BW (CV 7.1\%; Table 3).

The existence of an endogenous fraction (Table 3) agrees with previous nonisotopic studies in confirming the existence of such fraction in steers (Chen et al., 1990a; Verbic et al., 1990) and other species (Lindberg and Jackobson, 1990; Chen et al., 1990a; Balcells et al., 
Table 3. Duodenal flow of purine bases, urinary excretion of purine derivatives (PD), and estimated endogenous contribution.

\begin{tabular}{lllllr}
\hline Animal & Cow 1 & Cow 2 & Cow 3 & Mean & SD \\
\hline $\begin{array}{l}\text { Duodenal flow (mmol/d) } \\
\text { Urinary excretion }\end{array}{ }^{1}$ (mmol/d) & 226.9 & 282.2 & 372.8 & 293.9 & 42.5 \\
$\quad$ Allantoin & 188 & 244 & 256 & 229 & 20.9 \\
$\quad$ Total PD & 196 & 256 & 268 & 240 & 22.1 \\
$\quad \begin{array}{l}\text { Endogenous contribution } \\
\text { mmol/d }\end{array}$ & 62 & 63 & 51 & 59 & 3.9 \\
$\mu \mathrm{mol} / \mathrm{kg} \mathrm{BW}$ & & 556 & 440 & 512 & 36.4 \\
\hline
\end{tabular}

${ }^{1}$ Urinary PD excretion was calculated using inuline/creatine ratio to correct for urine losses.

1991 ; 1998) although comparison of results is constrained by differences in the methods employed. In growing steers the lower values $\left(\mu \mathrm{mol} / \mathrm{BW}^{0.75}\right)$ have been consistently recorded in intragastric fed animals (from 430 to 459; Fujihara et al., 1987; Verbic et al., $1990)$ or using the rumen-emptying technique (560, Giesecke et al., 1993), while the higher values correspond to fasted (609, Blaxter and Wood, 1951) or milkfed animals (600, Smith, 1975). Unfortunately, all these techniques cannot be applied to dairy cows without seriously affecting milk production, and therefore existing data are limited to feeding trials where the endogenous excretion is estimated as the intercept of the response to increasing levels of feeding. Published values are scarce and quite heterogeneous, from $259 \mu \mathrm{mol} / \mathrm{BW}^{0.75}$ (Kirchgessner and Windish, 1989) to 514 to $530 \mu \mathrm{mol} /$ BW $^{0.75}$ (Daniels et al., 1994).

Labeling microbial-N provides a source of naturally labeled PB suitable for describing purine metabolism in conventionally fed ruminants, especially in cattle where the incorporation of exogenous purine metabolites into tissues is negligible (Verbic et al., 1990). The high xanthine oxidase activity in the bovine intestine (Chen et al., 1990a) constrains the salvage of exogenous purines, and thus endogenous and exogenous purine compounds could be considered as independent compartments suitable to be labeled and measured (Orellana-Boero et al., 2001).

An interesting feature of this method is that it allows us to analyze the effect of physiological status on the endogenous excretion of PD. Values recorded in dry cows $\left(310 \pm 31.0 \mu \mathrm{mol} / \mathrm{BW}^{0.75}\right.$, Orellana-Boero et al., 2001) are close to those observed in growing steers (236 $\pm 6.0 ; \mu \mathrm{mol} / \mathrm{BW}^{0.75}$, Vicente, 2001), but in lactating animals the endogenous contribution seems to be much higher $\left(512.4 \pm 36.4 ; \mu \mathrm{mol} / \mathrm{BW}^{0.75}\right)$. It is known that the metabolism is affected by milk synthesis increasing the rate of protein synthesis and breakdown and probably the nucleic acid turnover, given the close relationship between both processes (Guernesey and Edelman, 1983). In spite of the significant changes observed in the absolute values of endogenous excretion $\left(\mu \mathrm{mol} / \mathrm{BW}^{0.75}\right)$, their relative contribution to total $\mathrm{PD}$ excretion remains unaltered (31.57, 24.3 and $27.7 \%$ in maintenance, growing, and lactating animals).

\section{Purine Derivative Excretion in Relation to Purine Bases Supply}

Urinary excretion. As shown in Table 3, the urinary excretion of PD in the absence of duodenal infusion of yeast nucleic acid $\left(2086 \pm 187 \mu \mathrm{mol} / \mathrm{BW}^{0.75}\right)$ was much higher than estimated endogenous losses, reflecting the supply from ruminal microbes in a normal fed cow (Orellana-Boero et al., 2001). Furthermore, it responded significantly $(P<0.001)$ to the duodenal infusion of RNA (Tables 4 and 5) with an average equimolar recovery rate of the infused purines of 0.44 and 0.74 in early and late lactation $(P<0.001)$. Unexplained variation accounted for only $4.4 \%$ of total variance, and it was in the range of previous reports (Balcells et al., 1993; Vagnoni et al., 1997).

As shown in Table 6, daily excretion of total purine derivatives ( $\mathrm{y}, \mathrm{mmol}$ per day) was linearly related to the duodenal input of PB ( $\mathrm{x}, \mathrm{mmol}$ per day) without significant improvement in the variation explained when a quadratic component was additionally considered. This result agrees well with previous observations in steers (Martín-Orúe et al., 2000; Orellana-Boero et al., 2001) and lactating cows (Daniels et al., 1994; Vagnoni et al., 1997) although Verbic et al. (1992) reported a curvilinear relationship between both parameters at low purine flow in growing steers. When the difference between lactation stages was tested by an homogeneity test of regression (Steel and Torrie, 1980), the existence of different slopes $(P<0.01)$ and a common intercept $(P>0.1)$ became apparent. With due caution for the small number of animals used and the high residual variation recorded in late lactation $(r=0.797)$, these results suggest that urinary recovery of duodenal purines is not constant throughout lactation. The equimolar recovery in late lactation, estimated from regression $(0.627 \pm 0.21)$ or from individual values $(0.74 \pm 0.04)$, is comparable to those previously reported by Orellana- 
Table 4. Duodenal flow of purine bases (PB) and urinary excretion of purine derivatives (PD) (mmol/d) in dairy cows infused through the duodenum with different amounts of nucleic acids in early and late lactation.

\begin{tabular}{|c|c|c|c|c|c|c|c|c|c|c|}
\hline \multirow[b]{2}{*}{$\begin{array}{l}\text { Infused RNA (mmol/d) } \\
\text { Duodenal flow of PB (mmol/d) }\end{array}$} & \multicolumn{3}{|c|}{ Early lactation } & \multirow{2}{*}{ SEM } & \multirow{2}{*}{$P<<^{\mathrm{a}}$} & \multicolumn{3}{|c|}{ Late lactation } & \multirow{2}{*}{ SEM } & \multirow{2}{*}{$P<$} \\
\hline & $\begin{array}{r}0 \\
294\end{array}$ & $\begin{array}{r}75 \\
369\end{array}$ & $\begin{array}{l}150 \\
444\end{array}$ & & & $\begin{array}{r}0 \\
299\end{array}$ & $\begin{array}{r}75 \\
374\end{array}$ & $\begin{array}{l}150 \\
449\end{array}$ & & \\
\hline Allantoin & 229 & 253 & 277 & 14.1 & NS & 227 & 278 & 354 & 18.0 & * \\
\hline Uric acid & 11 & 12 & 22 & 2.4 & NS & 32 & 45 & 36 & 4.1 & NS \\
\hline Total PD & 240 & 265 & 299 & 11.8 & * & 259 & 322 & 390 & 17.1 & $* *$ \\
\hline $\mathrm{PD} /$ creatinine ratio & 2.1 & 2.3 & 2.5 & 0.10 & $*$ & 2.4 & 3.2 & 3.9 & 0.04 & ** \\
\hline
\end{tabular}

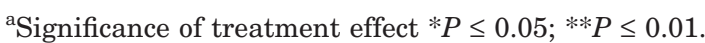

${ }^{\mathrm{b}}$ Chen et al. (1990b).

Boero et al. (2001) and Vagnoni et al. (1997) in dry and lactating cows $(0.83$ to 0.86$)$ or by Verbic et al. (1992) and Beckers and Théwis (1994) in growing steers $(0.77$ to 0.70$)$. However, in early lactation the proportion of duodenal $\mathrm{PB}$ recovered in the urine $(0.44 \pm 0.063)$ was significantly lower $(P<0.01)$. No information is available on the effect of the physiological status on PD metabolism, but the difference between lactation stages may be related to lower efficiency of absorption and metabolism of purine bases in early lactation due to over saturation by the experimental infusion of RNA. This suggestion could be supported by the results of Scharrer and Amman (1980), who showed the limited ability of purine transport mechanisms throughout the gut wall. However, the fact that duodenal flow of PB was similar in both phases ( $294 \pm 42.5$ and $298 \pm 35.1$ for early and late lactation, respectively) seems to preclude explaining this effect by differences in availability of the substrate. If lactation affects the profile of enzymes involved in purine metabolism (Johnson et al., 1998), it would explain changes in the efficiency of absorption and metabolism or alternatively the partitioning between renal and nonrenal routes.

Mammary excretion. The mean concentration of $\mathrm{PD}$ in milk and the daily excretion through the mammary gland are presented in Table 5. Allantoin was the predominant PD in milk, but the contribution of uric acid was much higher than in urine, accounting for $0.358 \pm$ 0.023 of total milk PD, independently of the duodenal supply of $\mathrm{PB}$. The high proportion of uric acid in milk compared to urine confirms previous results in milking cows (Giesecke et al., 1994; Gonda and Lindberg, 1997) and ewes (Martín-Orúe et al., 1996), but unlike ewes' milk (Martín-Orúe et al., 1996), no significant amounts of xanthine or hypoxanthine (less than $2 \mu \mathrm{mol} / \mathrm{L}$ ) were detected in cows' milk. Therefore, allantoin plus uric acid accounted for the total PD. Mean excretion rate of PD ranked from 3.99 to $10.23 \mathrm{mmol} / \mathrm{d}$ and on average only represented $0.021 \pm 0.002$ of the PD excreted in urine and $0.019 \pm 0.0026 \%$ of total excretion. These values agree well with those reported by others using similar analytical techniques (Giesecke et al., 1994;

Table 5. Duodenal flow of purine bases (PB) and milk concentration and excretion of purine derivatives (PD) (mmol/d) in dairy cows infused through the duodenum with different amounts of nucleic acid at early and later lactation.

\begin{tabular}{|c|c|c|c|c|c|c|c|c|c|c|}
\hline \multirow{3}{*}{$\begin{array}{l}\text { Infused RNA (mmol/d) } \\
\text { Duodenal flow of PB (mmol/d) }\end{array}$} & \multicolumn{3}{|c|}{ Early lactation } & \multirow{3}{*}{$\begin{array}{l}\text { SEM } \\
150\end{array}$} & \multirow{3}{*}{$P<<^{\mathrm{a}}$} & \multicolumn{3}{|c|}{ Late lactation } & \multirow{3}{*}{$\begin{array}{l}\text { SEM } \\
150\end{array}$} & \multirow{3}{*}{$P<\mathrm{a}$} \\
\hline & 0 & 75 & & & & & 0 & 75 & & \\
\hline & 294 & 369 & 445 & & & 299 & 374 & 449 & & \\
\hline Allantoin & 165 & 193 & 244 & 8.1 & $* * *$ & 172 & 220 & 246 & 8.1 & ** \\
\hline Uric acid & 115 & 133 & 160 & 10.9 & NS & 75 & 108 & 110 & 6.4 & * \\
\hline Total PD & 280 & 325 & 404 & 7.4 & $* * *$ & 246 & 328 & 356 & 11.3 & ** \\
\hline \multicolumn{11}{|l|}{ Daily excretion in milk $(\mathrm{mmol} / \mathrm{d})$} \\
\hline Total PD & 7.23 & 8.86 & 10.23 & 0.36 & $*$ & 3.99 & 6.28 & 6.43 & 0.39 & $*$ \\
\hline \multicolumn{11}{|l|}{ Recovery of infused purines as milk derivatives } \\
\hline Corrected for a digestibility of $0.92^{\mathrm{b}}$ & & 0.023 & 0.019 & & & & 0.033 & 0.020 & & \\
\hline
\end{tabular}

a Significance of treatment effect $* P \leq 0.05 ; * * P \leq 0.01 ; * * * P \leq 0.001$.

${ }^{\mathrm{b}}$ Chen et al. (1990b). 
Table 6. Relationship between duodenal flow of PB (x; mmol/d) and PD in urine and milk (y; mmol/d): $y=a+b x$.

\begin{tabular}{|c|c|c|c|c|c|c|c|c|c|c|c|c|c|c|}
\hline $\mathrm{Y}$ & \multicolumn{4}{|c|}{ Early lactation } & \multicolumn{4}{|c|}{ Late lactation } & \multicolumn{2}{|c|}{ Significance } & \multicolumn{4}{|c|}{ Pooled } \\
\hline Urinary excretion $(\mathrm{mmol} / \mathrm{d})$ & 103.6 & 0.44 & 0.93 & 16.3 & 84.21 & 0.63 & 0.79 & 48.3 & NS & $* *$ & - & - & - & - \\
\hline Milk excretion (mmol/d) & 3.42 & 0.014 & 0.89 & 0.72 & 1.42 & 0.011 & 0.57 & 48.3 & NS & NS & 2.53 & 0.013 & 0.672 & 2.04 \\
\hline
\end{tabular}

$* * P \leq 0.01$

Martín-Orúe et al., 1996; Gonda and Lindberg, 1997), but are higher than those recorded by colorimetric determination of allantoin (Kirchgessner and Kreuzer, 1985). In spite of the low contribution of milk to PD excretion, milk allantoin and uric acid were not constant and responded significantly to the experimental infusion of RNA $(P<0.01$ and $P<0.05$, for milk concentration and excretion). This response was caused mainly by allantoin, although uric acid (excretion and concentration) also responded significantly (Table 5). The relationship between milk excretion of PD and duodenal flow of PB was linear and did not differ between early and late lactation. The same results were observed with milk PD concentration as dependent variable. Therefore, in both cases a pool equation was considered for the whole lactation as shown in Table 6 .

The present findings provide new information on the excretion rate of allantoin and uric acid in lactating dairy cows. Although this subject has been dealt with extensively in the literature, it is necessary to remark that in most of the cited reports PD excretion and milk yield are positively correlated. Variations in rumen microbial synthesis are associated to changes in energy and protein to the host animal and as a consequence in milk yield. The present experimental design attempts to break this autocorrelation and experimentally induced variation in duodenal purine flow was independent of milk yield as shown clearly in Figure 1. Indeed, there was a modification in milk yield between early and late lactation but not within each stage.

Another important point when the relationships between duodenal input and urinary or milk output are analyzed is to obtain a consistent estimate of the duodenal flow of microbial protein or PB or both. Most of the existing information in lactating cows has been obtained using theoretical values predicted from protein evaluation systems (AFRC, 1992; Shingfield and Offer, 1998) or by measuring microbial protein synthesis in fistulated animals (Lebzien et al., 1993). In both cases, measurements of rumen microbial synthesis are subjected to errors owed to uncertainties in the estimates of both duodenal flow and microbial $\mathrm{N}$.

The duodenal infusion of RNA allows an exact measurement of the variation in the duodenal flow of $\mathrm{PB}$ and was successful in breaking down the colinearity between milk yield and duodenal flow. In this condition, PD excretion in milk did reflect variations in the duodenal input of PB. However, while in early lactation the duodenal input of $\mathrm{PB}$ explained about $80 \%$ of the variation in milk PD excretion, in late lactation the correlation (Table 6) was much lower and differences between cows reached statistical significance $(P<0.05)$. When data were subjected to covariance analysis considering individuals (cow) as covariate, nonexplained variation decreased from 66 to $19 \%(P<0.04)$. The variation in milk production in late lactation among cows was greater so that the correlation between duodenal input and milk output of PD was lower. Milk production in early lactation was quite constant: $26.2,25.4$, and 27.2 $\mathrm{L} / \mathrm{d}$ but the decline throughout lactation was irregular, and milk yield in late lactation was less homogeneous: $19.2,14.8$, and $19.1 \mathrm{~L} / \mathrm{d}$ for cow 1,2 , and 3, respectively. Trying to evaluate the effect on PD excretion of both components, milk yield and PB input, data were analyzed by stepwise regression. Milk production was the variable that showed the highest correlation, but with the inclusion of the duodenal flow of $\mathrm{PB}$, a second independent variable did reduce significantly $(P<0.05)$ the unexplained variations by $15 \%$. In agreement with previous results (Gisecke et al., 1994; Martín-Orúe et al., 1996; Gonda et al., 1997), the correlation between milk yield and PD (or allantoin) excretion by the mammary gland would certainly limit the use of milk allantoin or PD as an index of the microbial protein supply in dairy cow.

In the present study, account was not taken for the endogenous contribution of purine derivatives to mammary excretion. We tried, as in urine, to isolate allantoin from defatted and deproteinized milk, but the high dilution of allantoin precluded a consistent determination of the isotopic enrichment of allantoin-N.

Relationship between purine absorption and excretion in urine or milk in lactating cows. If the relationship between purine absorption and excretion have to be used for prediction purposes, the previous concepts need to be integrated into the explanation of variation occurring under different conditions. In sheep the relationship between exogenous supply and urinary 


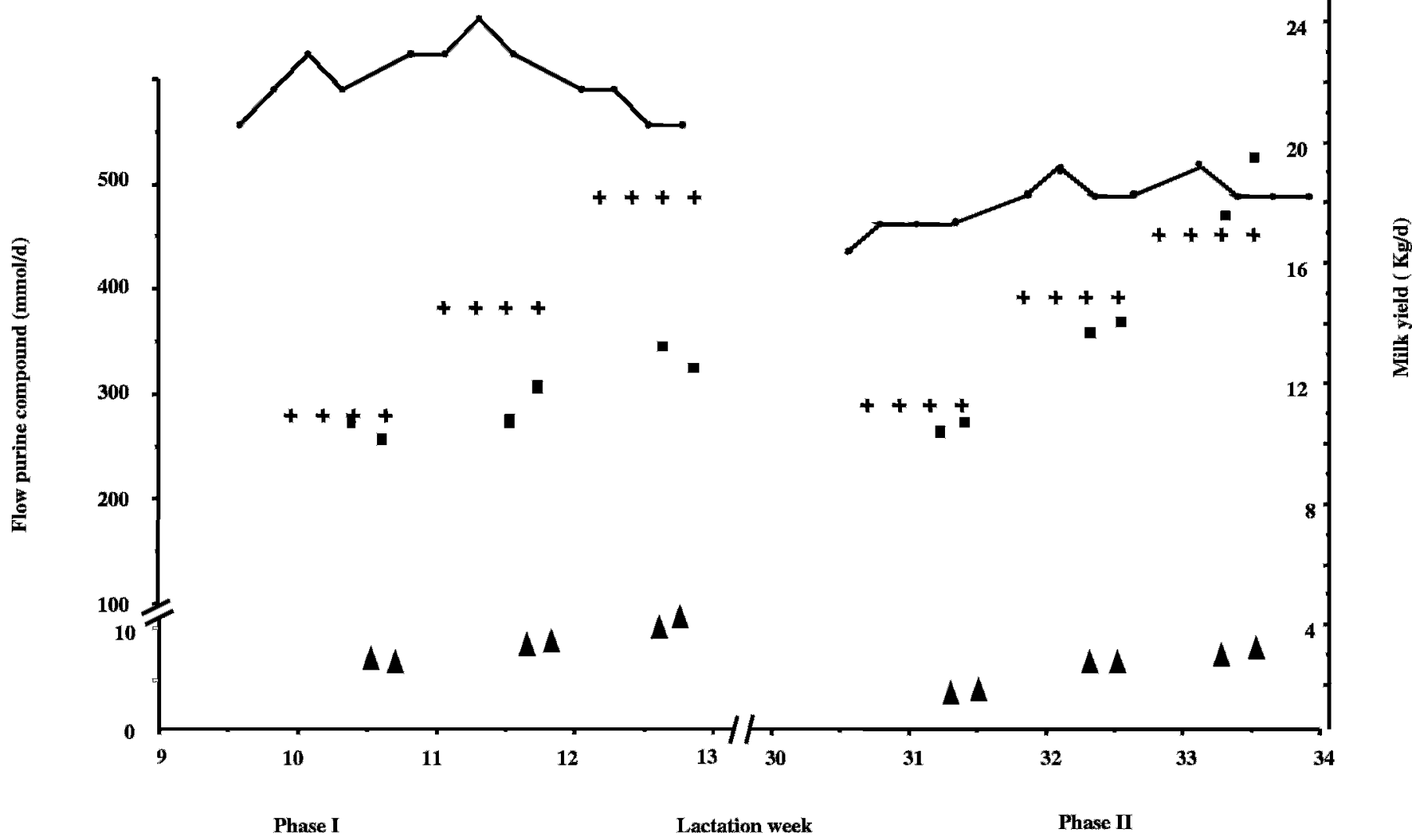

Figure 1. Relationship between duodenal flow purine bases (+) with urinary ( $\mathbf{\square})$ and mammary ( $\mathbf{\Delta})$ excretion of purine derivatives together with daily variation in milk yield (-) through two experimental phases.

output seems to be curvilinear (Chen et al., 1990b; Balcells et al., 1991) due to the biochemical feedback of the de novo synthesis by the incorporation of exogenous PD. Cattle have a high concentration of xantine oxidase in intestinal mucosa and liver (Chen et al., 1990a; Ojeda and Parra, 1999), and the biochemical feedback and salvage of exogenous purines are restricted to the gastrointestinal tract and liver (Balcells et al., 1992). Therefore, the endogenous contribution to PD excretion in cattle is always present, and the relationship between purine absorption and PD excretion has been described as almost linear in steers (Verbic et al., 1990) and dry cows (Orellana-Boero et al., 2001), as well as in milking in cows as it has been previously shown. Thus, plasma-PD available ( $\mathrm{mmol}$ per day) to be excreted by kidney in a constant proportion $B$, has a double origin:duodenal absorption $(X)$ and endogenous contribution $(A)$. The relationship between PB absorption and urinary excretion of PD (Y, mmol per day) can be adjusted by the function: $Y=B(X+A)$ or $Y=B X+a$, where $A \times B=a$, which is the constant endogenous contribution determined by isotope dilution (58.86 $\mathrm{mmol} / \mathrm{d}$ or $512 \mu \mathrm{mol} / \mathrm{BW}^{0.75}$ ) and $B$ the urinary recovery $(Y)$ of duodenal absorbed PB $(X)$. If duodenal PB are absorbed through the gut in a high and constant proportion (true digestibility, $\mathrm{TD}=0.913$, Chen et al., 1990b), then urinary recovery of duodenal PB (x) could be defined by the following equation $Y=a+b x$, where $b=$ $B / T D$ and $x=$ duodenal flow of PB. Integration of these concepts and considering a differential equimolar recovery of duodenal $\mathrm{PB}$, allows data adjustment into the regression model with a constant intercept $(Y=a+b x)$ with the following result: early lactation: $y=58.86$ ( \pm $3.89)+0.56( \pm 0.0164) x ; r=0.90 ; R S D=18.70 ; n=9$; later lactation: $y=58.86( \pm 3.89)+0.70( \pm 0.046) x ; r=0.80$; $R S D=44.58 ; n=9$. The constants $b$ of 0.56 and 0.70 , 
in early and late lactation, imply that absorbed PB $(X)$ were excreted in urine $(B=b / T D)$ in a proportion of 0.61 and 0.77 , respectively. It means that between 14 and $32 \%$ of absorbed $\mathrm{PB}$ were lost through routes other than renal routes. Among them, milk represents only a small (3.34 and $1.6 \%$ for early and late lactation, respectively), but significant fraction. This fraction being modified by changes in duodenal flow of PB and milk yield as described by the following prediction equation: $y=-5.14+0.376( \pm 0.428) x_{1}+0.011( \pm 0.0024) x_{2} ; r=$ $0.93 ; R S D=0.84 ; n=18$, where PD excretion in milk $\left(y\right.$, mmol per day) increases with milk yield $\left(x_{1}, \mathrm{~kg}\right.$ per day) and duodenal flow of purine bases $\left(x_{2}, \mathrm{mmol}\right.$ per day).

\section{IMPLICATIONS}

Plasma PD are excreted through the mammary gland in a small proportion that is related to the duodenal absorption of purine bases. However, this way of excretion mainly depends on the milk yield, and it precludes milk PD as a potential index to estimate duodenal flow of purine bases.

If $\mathrm{PD}$ excretion in milk is not considered, the relationship between absorption and excretion of purine compounds would be underestimated by less than $7 \%$ in dairy cows.

\section{ACKNOWLEDGMENTS}

This work has been supported by the CICYT Project PB98-01601. During the realization of this experiment, the stage of M. González-Ronquillo was supported by the Instituto de Cooperation Iberoamericana (Spain) and Universidad Autónoma del Estado de Mexico (Mexico). Thanks are given to R. Redondo Faculty of Sciences U.A.M. for isotope analyses in the Lab of stable isotopes.

\section{REFERENCES}

AFRC. 1992. Agricultural and Food Research Council: Technical Committee on responses to nutrients. Report no. 9. Nutritive Requirements of Ruminant Animals: Protein Nutrition Abstracts and Reviews, Ser. B. 62:787-835.

Aharoni, Y., and H. Tagari. 1991. Use of nitrogen-15 determinations of purine nitrogen fraction of digesta to define nitrogen metabolism traits in the rumen. J. Dairy Sci. 74:2540-2547.

Balcells, J., J. A. Guada, C. Castrillo, and J. Gasa. 1991. Urinary excretion of allantoin and allantoin precursors by sheep after different rates of purine infusion into the duodenum. J. Agric. Sci. 116:309-317.

Balcells, J., D. S. Parker, C. J. Seal. 1992. Purine metabolite concentrations in portal and peripheral blood of steers, sheep and rats. Comp. Biochem. Physiol. 101B:633-636.

Balcells, J., J. A. Guada, C. Castrillo, and J. Gasa. 1993. Rumen digestion and urinary excretion of purine derivatives in response to urea supplementation of sodium-treated straw fed to sheep. Br. J. Nutr. 69:721-732.

Balcells, J., J. M. Ganuza, J. F. Pérez, S. M. Martín-Orúe, and M. González Ronquillo. 1998. Urinary excretion of purine derivatives as an index of microbial nitrogen intake in growing rabbits. Br. J. Nutr. 79:373-380.

Beckers, Y., and A. Théwis. 1994. Excretion of purine derivatives in urine of Belgian blue bulls following duodenal infusion from Torula yeast. Proc. Soc. Nutr. Physiol. 3:235.

Blaxter, K. L., and W. A. Wood. 1951. The nutrition of the young Ayrshire calf. 3. The metabolism of the calf during estimation and subsequent realimentation. Br. J. Nutr. 5:29-55.

Broderick, G. A., and N. L. Merchen. 1992. Markers for quantifying microbial protein synthesis in the rumen. J. Dairy Sci. 75:2618-2632.

Chen, X. B., E. R. Ørskov, and F. D. DeB. Hovell. 1990a. Excretion of purine derivatives by ruminants: Endogenous excretion, differences between cattle and sheep. Br. J. Nutr. 63:121-129.

Chen, X. B., F. D. DeB. Hovell, E. R. Ørskov, and D. S. Brown. 1990b. Excretion of purine derivatives by ruminants: Effect of exogenous nucleic acid supply on purine derivative excretion by sheep. Br. J. Nutr. 63:131-142.

Chen, X. B., D. J. Kyle, E. R. Ørskov, and F. D. DeB. Hovell. 1991. Renal clearance of plasma allantoin in sheep. Experimental Physiol. 76:59-65.

Daniels, Z. M., X. B. Chen, D. J. Kyle, K. Sinclair, and E. R. Ørskov. 1994. Purine derivatives in urine and plasma of lactating cows given different levels of feed intake. Anim. Prod. 58:453 (Abstr).

Faichney, G. J. 1975. The use of markers to partition digestion within the gastrointestinal tract of ruminants. Pages 277-291 in: Digestion and Metabolism in Ruminant. I. W. McDonald and A. C. I. Warner, ed. University of New England Publishing Unit, Armidale.

Fujihara, T., E. R. Ørskov, P. J. Reeds, and D. J. Kyle. 1987. The effect of protein infusion on urinary excretion of purine derivatives in ruminants nourished by intragastric nutrition. J. Agric. Sci. Camb. 109:7-12.

Giesecke, D., J. Blasliemker, K. H. Südekum, and M. Staingassinger. 1993. Plasma level, clearance and renal excretion of endogenous and ruminal purines in the bovine. J. Anim. Physiol. Anim. Nutr. 70:180-189

Giesecke, D. J., L. Ehrentreich, and M. Staingassinger. 1994. Mammary and renal excretion of purine metabolites in relation energy intake and milk yield in dairy cows. J. Dairy Sci. 77:2376-2381.

Gonda, H. L., M. Emmanuelson, and M. Murphy. 1996. The effect of roughage to concentrate ratio in the diet on nitrogen and purine metabolism in dairy cows. Anim. Feed Sci. Technol. 64:27-42.

Gonda, H. L., and J. E. Lindberg. 1997. Effect of diet on milk allantoin and its relationship with urinary allantoin in dairy cows. J. Dairy Sci. 80:364-373.

Guernesey, D. L., and J. S. Edelman. 1983. Regulation of thermogenesis by thyroid hormones. Pages 293-324 in Molecular Basis of thyroid Hormone Action. J. Hoppenheimer and H. H. Samuels, ed. Academic Press, New York.

Johnson, L. M., J. H. Harrison, and R. E. Riley. 1998. Estimation of the flow of microbial nitrogen to duodenum using urinary uric acid or allantoin. J. Dairy Sci. 81:2408-2420.

Jung, K., S. Klozet, and B. Schulze. 1990. Refinements of assay for low concentrations of inulin in serum. Nephron 54:360-361.

Kirchgessner Von, M., and M. Kreuzer. 1985. Harstoff und allantoin in der Milch und Allantoinausscheidung von Kühen wäherend ung nach Verfütterung zu hoher und zu niedriges Proteinmengen. 5. Mitteilung. Zum Einflub von proteinfehlernáhrung bei laktiereden Kúben und daraus entshenden Nachwirkirkungen. J. Anim. Physiol. Anim. Nutr. 70:82.

Kirchgessner Von, M., und W. Windish. 1989. Harnstoffehalt der Milch und Allantounaussscheidung von kühen während und nach Energie- und Ptoteinmangel. J. Anim. Physiol. Anim. Nutr. 62:113-118.

Lebzien, V. P., D. Giesecke, Wiesmayr, und K. Rohr. 1993. Messung der mikrobiellen proteinsynthese im pansen von Kühen mittels $15 \mathrm{~N}-B e s t i m m u n g$ im Duodenalchymus und Allantoinausscheidungin ther milch. J. Anim. Physiol. Anim. Nutr. 70:82-88.

Liang, J. B., M. Matsumoto, and B. A. Young. 1994. Purine derivative excretion and ruminal microbial yield in Malaysian cattle and swamp buffalo. Anim. Feed Sci. Technol. 47:189-199. 
Lindberg, J. E., and K. G. Jacobson. 1990. Nitrogen and purine metabolism at varying energy and protein supplies in sheep sustained on intragastric infusion. Br. J. Nutr. 64:359-370.

Martín-Orúe, S. M., J. Balcells, J. A. Guada, and C. Castrillo. 1995. Endogenous purine and pyrimidine derivative excretion in pregnant sows. Br. J. Nutr. 73:375-385.

Martín-Orúe, S. M., C. Dapoza, J. Balcells, and C. Castrillo. 1996. Purine derivatives excretion in lactating ewes straw diets with different levels of fishmeal. Anim. Feed Sci. Technol. 63:341-346.

Martín-Orúe, S. M., J. Balcells, J. A. Guada, M. Fondevila. 2000. Microbial nitrogen production in growing heifers: Direct measurement of duodenal flow of purine bases versus urinary excretion of purine derivatives as estimation procedures. Anim. Feed Sci. Technol. 88:171-188.

Ojeda, A., and O. Parra. 1999. Urinary excretion of purine derivatives as an index of microbial protein supply in cross-bred (Bos indicus $\times$ Bos taurus) cattle in tropical environment. In: Nuclear based technologies for estimating microbial protein supply in ruminant livestock. IAEA-TECDOC-1093. Viena.

Orellana-Boero, P., J. Balcells, S. M. Martín-Orúe, J. B. Liang, and J. A. Guada. 2001. Excretion of purine derivatives in cows: Endogenous contribution and recovery of exogenous purine bases. Livest. Prod. Sci. 68:243-250.

Pérez, J. F., J. Balcells, J. A. Cebrian, and S. M. Martín-Orúe. 1998. Excretion endogenous and exogenous purine derivatives in sheep. Effect of increases concentrate intake. Br. J. Nutr. 9:237-240.

SAS User's Guide: Statistics, Version 6.03. 1998. SAS Inst., Inc. Cary, NC.

Scharrer, E., and B. Amman. 1980. Intestinal transport of amino acids and pyrimides in sheep. Vol. 1. Pages 149-158 in Proc. of the 3rd EAAP. Symp. on protein metabolism and nutrition. Brausnchweig. F.G. Germany.

Shingfield, K. J., and N. W. Offer. 1998. Evaluation of milk allantoin excretion as an index of microbial protein supply in lactating dairy cows. J. Anim. Sci. 67:371-385.
Siddons, R. C., J. Paradine, D. E. Beever, and P. R. Cornell. 1985. Ytterbium acetate as a particulate-phase digesta-flow marker. Br. J. Nutr. 509-519.

Smith, R. H. 1975. Nitrogen metabolism in the rumen and the composition and nutritive value of nitrogen compounds entering the duodenum. Pages 399-415 in Digestion and metabolism in the ruminant. McDonald, I. W., and A. C. I. Warner, ed. New England Univ. Publish Unit.

Steel, R. G. D., and J. H. Torrie. 1980. Principles and Procedures of Statistic: A Biomedical Approach. 2nd ed. McGraw-Hill Book Co. New York, NY.

Surra, J., J. A. Guada, J. Balcells, and C. Castrillo. 1997. Renal and salivary clearance of purine derivatives in sheep. J. Anim. Sci. 65:83-91.

Susmel, P., M. Sphangero, B. Stefanon, C. R. Mills, and E. Plazzotta 1994. Digestibility and allantoin excretion in cows fed diets differing in nitrogen content. Livest. Prod. Sci. 39(1):97-99.

Vagnoni, D. B., and G. A. Broderick. 1997. Effects of supplementation of energy or ruminally in degraded protein to lactating cows fed alfalfa hay or silage. J. Dairy Sci. 80:1703-1712.

Vagnoni, D. B., G. A. Broderick, M. K. Clayton, R. D. Hatfield. 1997. Excretion of purine derivatives by Holstein cows abomasally infused with incremental amounts of purines. J. Dairy Sci. 80:1695-1702.

Verbic, J., X. B. Chen, N. A. McLeod, and E. R. Ørskov. 1990. Excretion of purine derivatives by ruminants. Effect of microbial nucleic acid infusion on purine derivative excretion by steers. J. Agric. Sci. Camb. 114:243-248.

Vicente, M. F. 2001. Efecto de la suplementación proteica sobre el aporte al duodeno y aminoácidos digestibles en terneros de cebo intensivo. Tesis Doctoral. Universidad de Zaragoza. Facultad de Veterinaria.

Wattiaux, M. A., and J. D. Reed. 1995. Fractionation of nitrogen isotopes by mixed ruminal bacteria. J. Anim. Sci. 73:257-266. 